\title{
Diet selection and utilization by llama and sheep in a high altitude-arid rangeland of Bolivia
}

\author{
DIDIER GENIN, ZENOBIO VILLCA, AND PERCY ABASTO
}

\begin{abstract}
Authors are range scientist and graduate students, ORSTOM Institut Francais de Recherche Scientifique pour le Développment en Coopération, C.P. 9214, La Paz, Bolivia.
\end{abstract}

\begin{abstract}
Botanical composition of llamas and sheep diets were quantified monthly during 1 year in the arid highlands of Bolivia to identify competition between these species for forage resources. Results indicated higher proportions of coarse bunchgrasses in llamas diets ( 48 to $75 \%$ ) than in sheep ( 37 to $68 \%$ ), while sheep consumed more soft herbs and grasses than llamas (25 to $45 \%$, and 8 to $25 \%$, respectively). Llamas had higher $(P<0.05)$ digestion coefficients than sheep for organic matter, dry matter, crude protein, and fiber fractions of the principle bunchgrass paja brava (Festuca orthophylla) during the vegetative phenological stage. Shrubs represented less than $20 \%$ of the diet components in both llamas and sheep. A canonical discriminant analysis showed that there was not a strong dietary overlap between these species, and suggested that mixed herds could allow a better utilization of the overall available forage.
\end{abstract}

Key Words: diet selection, llama, sheep, dietary, overlap, digestibility, arid highlands, Bolivia

Livestock production is the dominant activity of small holders inhabiting the arid highlands of Bolivia. Llamas are characteristic of this zone, which supports $70 \%$ of the world llama population (Wheeler 1991). This species is generally associated with sheep in the farming systems. The only sources of feed are native rangelands, including several unique plant communities, especially adapted to the adverse climate of the area. Among these, the so-called "pajonales" occupy extensive areas and are formed by tall, coarse bunchgrasses, of the Stipa and Festuca genera. Alzerreca and Lara (1988) reported that Festuca orthopylla, called "Paja brava" or "iru ichu" by natives, is the dominant species in almost $30 \%$ of the area of central highlands of Bolivia. This species is considered a poor forage, due to its roughness and its very low nutritive value. For example, Alzerreca and Cardozo (1991) reported crude protein content varied from 2.5 to $7.6 \%$ dry matter. Nevertheless, paja brava is sometimes the only available forage for the herds.

Very few studies have focused on the feeding behavior of llamas and sheep in the Andes. San Martin (1987), and Pfister et al. (1989), showed that sheep were more selective grazers than camelids and occupied different foraging niches in the semi-humid Andes of Peru. In the arid andes of Bolivia, knowledge of diet \footnotetext{
The authors wish to thank $L$. Markowicz and $M$. Gonzales for helpful comments on
the manuscript. This work was carried out within the collaborative program between the Bolivian Institute of Agropastoral Technology (IBTA) and the ORSTOM entitled "Dynamics of production systems in the bolivian altiplano".

Manuscript accepted 26 Nov. 1993.
}

selection of different grazing species is necessary for a better management of the fragile highland vegetation.

The differences between llama and sheep in the ability to digest forage are better documented. San Martin and Bryant (1989) reviewed previous comparative digestibility trials, reporting generally higher digestion coefficients for llamas than for sheep. They pointed out that these differences increased as the overall quality of the diet decreased. Concerning coarse bunchgrasses, Maiza and Cardozo (1992) found a digestion coefficient for dry matter of Stipa ichu almost $20 \%$ greater in llamas than in sheep. Lailhacar (1990), reported in vitro dry matter digestion coefficients of paja brava between $38 \%$ and $52 \%$, but did not precize the rumen inocula used.

The objectives of this study were: (1) to quantify the botanical composition of diets of llamas and sheep in the arid highlands of Bolivia, with special emphasis on the role of paja brava and, (2) to compare dry matter digestibility of paja brava in llama and sheep.

\section{Materials and Methods}

The study was conducted at Turco $\left(17^{\circ} 57^{\prime} \mathrm{S}, 68^{\circ} 15^{\prime} \mathrm{E}\right)$, in the Department of Oruro, Boliva. The elevation is $3,900 \mathrm{~m}$. Climate is arid tropical arid: annual precipitation averages $320 \mathrm{~mm}$, falling between December and March. Mean annual temperature is $7.6^{\circ}$ $\mathrm{C}$, with much larger diurnal variation than seasonal fluctuation. Frosts occur approximately 300 days per year. During the study period (October 1991-September 1992) rainfall was only $210 \mathrm{~mm}$.

A feeding behavior study was conducted at the estancia Chocolla, typical of the mixed camelid-sheep breeding system of the region. The herds were composed of 50 adult female llamas and 130 sheep. Vegetation of the 520-ha study area included:

- Pajonales - tall grass communities, dominated by the genera Stipa and Festuca, comprising $43 \%$ of the total feeding area,

-Tholares - shrub communities, dominated by shrubs of the genera Parastrephia, Baccharis, Fabiana and Tetraglochin, occupying $50 \%$ of the total feeding area.

- Bofedal and gramadal-short grasses and forbs communities, partly flooded, accounting for $2.5 \%$ of the total feeding area.

A detailed description of the vegetation has been presented by Moron et al. (1992).

Animals foraged on the entire feeding area during the whole year. Diet selection was determined monthly for 1 year (October 1991-September 1992) by direct observation of the animals, using the bite-count method (Reppert 1960; Meuret et al. 1985). Data were recorded during an entire daily feeding time for each species. Every 30 minutes, for a 10 minute period, the bite counts were 
recorded for a focal adult animal chosen randomly. The focal animal was changed every 30 minutes. In the bofedal-gramadal communities, all herbaceous species were considered a single group because of the difficulty in recognizing the species actually consumed. Simulations of bite weight for each forage species were made, following Stobbs (1973) and Meuret et al. (1985). Results are reported as the forage species contribution to diet, taking into account the grazing time spent in the different types of vegetation, as presented by Genin and Badan (1991), and Genin and Pijoan (1993).

Llama and sheep diets were analyzed using canonical discriminant analysis, a multivariate statistical technique that allows study of differences between 2 or more groups of data simultaneously (Hanley and Hanley 1982, Ortega 1991). This technique permits the separation of llama and sheep diets if forage selection is significantly different. Discriminant analysis was applied to the diet data pooled across all seasons, only including plant species or categories comprising more than $5 \%$ of the diet. To test for statistical significance among groups, the $\mathrm{F}$ ratio for the Mahalanobis distance between each pair of groups was calculated (Hanley and Hanley 1982).

A comparative digestion trial was then performed using paja brava as a unique source of feed. Threc 4-ycar-old malc llamas (mean weight $90 \mathrm{~kg}$ ), and three 2-year-old castrated criollo sheep (mean weight $21 \mathrm{~kg}$ ) were housed in metabolic cages at the experimental station of Turco (PROCATUR). Animals were fed ad libitum paja brava over 14 days. Fresh material of paja brava was collected daily, imitating the selection of free-ranging animals, during 2 periods in February and September, months within the wet and dry seasons, respectively. For the final 6 days, samples of feeds, orts, and faeces were collected and dried to determine dry matter digestibility (DMD) and for laboratory analyses. These included crude protein, crude fiber, ether extract, non nitrogen extract, and ash contents. Digestion coefficients were calculated on the basis of dry matter. Metabolizable energy (ME) was estimated based on organic matter digestibility, following Morgan (1974). An analysis of variance was performed to compare the differences in digestibility between llama and sheep. The Newman-Keuls test was used to compare digestion coefficients between species. Per-

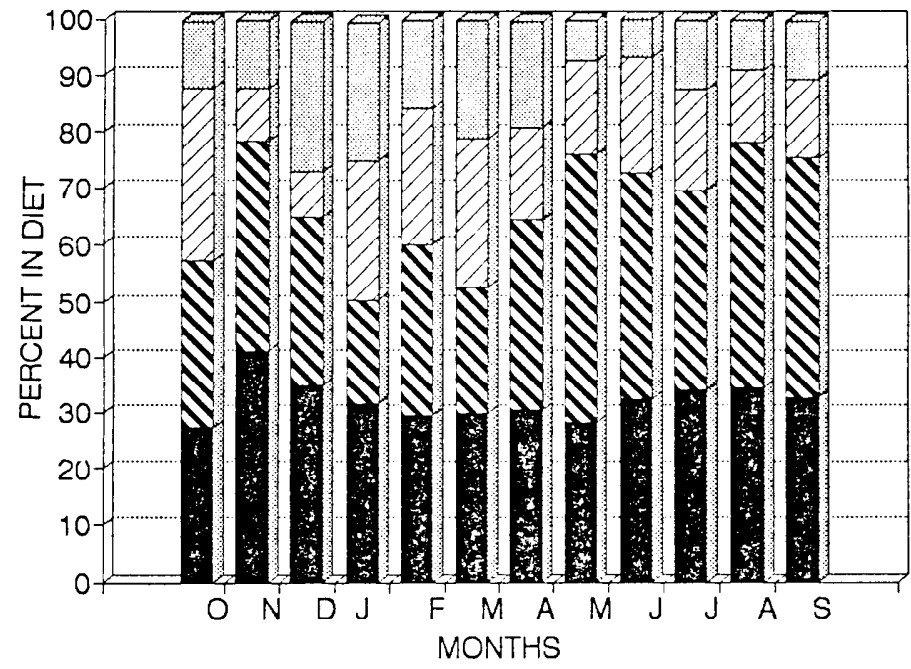

F. orthophylla

Q Other bunzhgrasses $Z 2$ soth neros/grasses $\square$ shrubs

Fig. 1. Annual fluctuation in the botanical composition of llama diets.

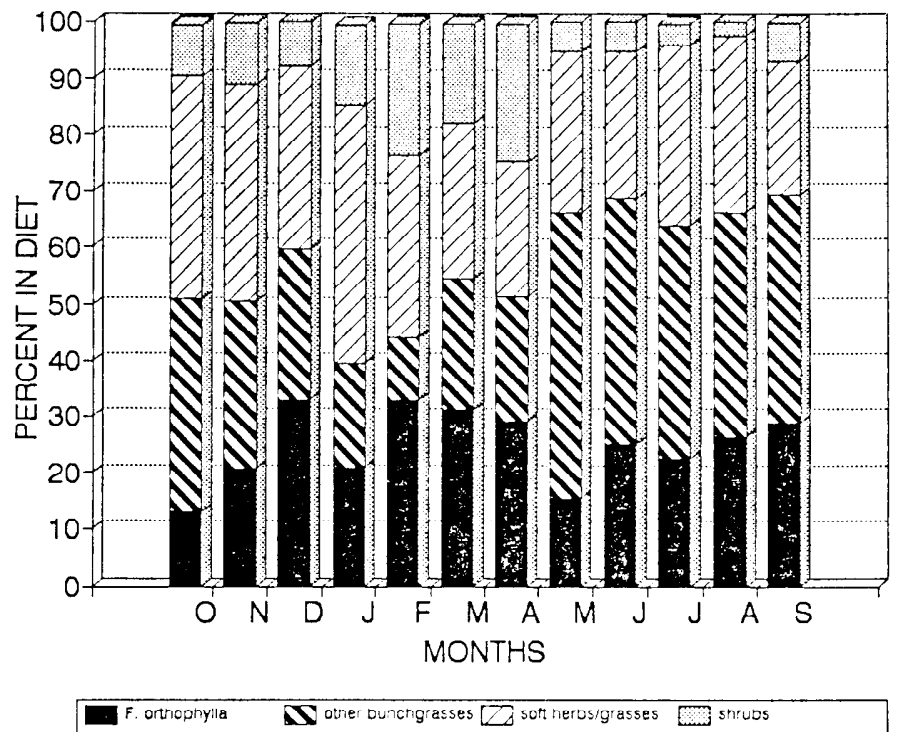

Fig. 2. Annual fluctuation in the botanical composition of sheep diets.

cent data were submitted to an arcsine transformation, following Steel and Torrie (1980).

\section{Results and Discussion}

\section{Botanical Composition of Diets}

Forages were grouped into 4 classes: paja brava, other coarse bunchgrasses, soft herbs and other grasses, and shrubs. Monthly contributions to diet of $F$. orthophylla, the other coarse bunchgrasses (Stipa ichu and $F$. dolichophylla), soft herbs and grasses (Calamagrostis heterophylla. Poa candamoana. Muhlenbergia peruviana, M. fastigiata, Malvastrum peruvianum, Distichlis humilis, etc...), and shrubs ( $P$. lephidophylla, P. quadrangularis, Baccharis incarum, Tetraglochin cristatus, Adesmia spinossissima) are shown in figure 1 for llama and figure 2 for sheep. A detailed description of diets by forage species, is presented by Villca (1993). Throughout the year, coarse bunchgrasses constituted the major component of diets selected by llama $(48-75 \%)$ and sheep $(37-68 \%)$. Llamas consumed 15 to $20 \%$ more $(P<0.05)$ of the coarse bunchgrasses than sheep, irrespective of season. Paja brava was the most consumed species by llama ( 20 to $41 \%$ ) and sheep ( 15 to $33 \%$ ).

Differences in consumption of soft herbs and grasses reached to $50.6 \%$ in the dry season (April to December), and $29 \%$ in the wet season (January to March), in favor of sheep.

Though the shrub foliage was abundant in the rangeland, shrubs represented less than $20 \%$ of the dietary components by both llamas and sheep, and were slightly more consumed by llama than by sheep (differences in consumption of $28(P<0.10)$ to $9 \%$ $(P>0.10)$ in wet and dry season, respectively).

San Martin (1987) found a similar spectrum for botanical composition of llama and sheep diets in a sub-humid zone of the peruvian highlands. Tall grasses comprised 42 and $25 \%$ to the diet of llama and sheep, respectively. Llamas are viewed primarily as grazer herbivores, and their feeding behavior specificity lies in their ability to consume large quantities of coarse bunchgrasses (San Martin 1989; Pfister et al. 1989).

The F-ratio for the most important forages consumed showed significant differences in consumption between llama and sheep for paja brava, gramadal, annual grasses, $C$. heterophylla, P. can- 
Table 1. F-ratios resulting from analysis of variance for animal species effects (llamas and sheep) on forage consumption by plant species or categories.

\begin{tabular}{lrl}
\hline \hline Forage species & $\mathrm{F}$ & $p>\mathrm{F}$ \\
\hline F. orthophylla & 17.59 & $0.0002^{* *}$ \\
S. ichu & 1.66 & 0.21 \\
$P$. lepidophylla & 1.36 & 0.25 \\
B. incarum & 18.80 & $0.0001^{* *}$ \\
A. spinossisima & 3.84 & $0.05\left(^{*}\right)$ \\
$T$. cristatus & 0.47 & 0.50 \\
$P$. candamoana & 10.78 & $0.0025^{* *}$ \\
C. heterophylla & 7.11 & $0.01^{* *}$ \\
Annual grasses & 11.84 & $0.0017^{* *}$ \\
F. dolichophylla & 0.49 & 0.49 \\
gramadal & 14.99 & $0.0005^{* *}$ \\
\hline
\end{tabular}

${ }^{* *}: p<0.01\left({ }^{*}\right): p<0.10$

damoana, and B. incarum (Table 1).

Results of canonical discriminant analysis are shown in figure 3. The first canonical axis (CAN1) allowed a complete discrimination of llama and sheep diets. Forages which strongly determined this axis were positively paja brava, $B$. incarum, $S$. ichu, $P$. lephidophylla and $P$. qudrangulare, and, negatively, gramadal, annual grasses, $P$. candamoana and $C$. heterophylla, Llama's diets were always positive scores on this axis (mean 2.38), while sheep's diets presented negative values throughout the year (mean -2.53 ). The CAN2 axis did not segregate any particular group.

These results support the data presented by Alvarez (1993), who compared winter diets of alpaca, llama, and sheep in the subhumid region of Puno, Peru.
Table 2. Chemical composition of Festuca orthophylla during wet (vegetative stage) and dry (mature stage) seasons.

\begin{tabular}{lccccccc}
\hline & DM & OM & CP & CF & EE & NFE & ash \\
\hline & & - & - & $\ldots$ & $-(\%)$ & $\ldots \ldots$ & $\ldots \ldots$ \\
Wet season & 56.2 & 94.9 & 6.6 & 44.0 & 1.0 & 38.3 & 3.9 \\
Dry season & 72.5 & 92.8 & 1.4 & 42.7 & 0.7 & 44.5 & 7.2 \\
\hline
\end{tabular}

Data tend to demonstrate that there is not a strong dietary overlap between llama and sheep in the arid highlands of Bolivia. It seems that mixed species herds allow a better utilization of forage resources than monospecific herds in this environment. This assumption was clearly demonstrated for sheep and cows in other situations (Nolan and Connolly 1977).

\section{Digestibility of $F$. orthophylla}

Chemical composition of paja brava showed that this species is a poor quality forage even in vegetative stage (Table 2). Llamas had higher digestion coefficients for paja brava than sheep, with a difference in dry matter digestibility of $23 \%$ and $5 \%$ during the wet and dry season trials, respectively (Table 3 ). Digestion coefficients in the vegetative stage were all significantly higher in llama than in sheep. Llamas generally have greater digestive efficiency than sheep for low and medium quality diets (San Martin and Bryant 1989). This may be explained by a longer retention time of digesta (San Martin 1987), and by more frequent contractions of the forestomach, the rumination cycle, and the higher ratio of salivary flow to forestomach size in llama (San Martin and Bryant 1989). These characteristics provide for more efficient maceration, mixing, and absorption of digesta in llama. Finally, nitrogen metabolism has been shown to be more efficient in llama (Engelhardt and

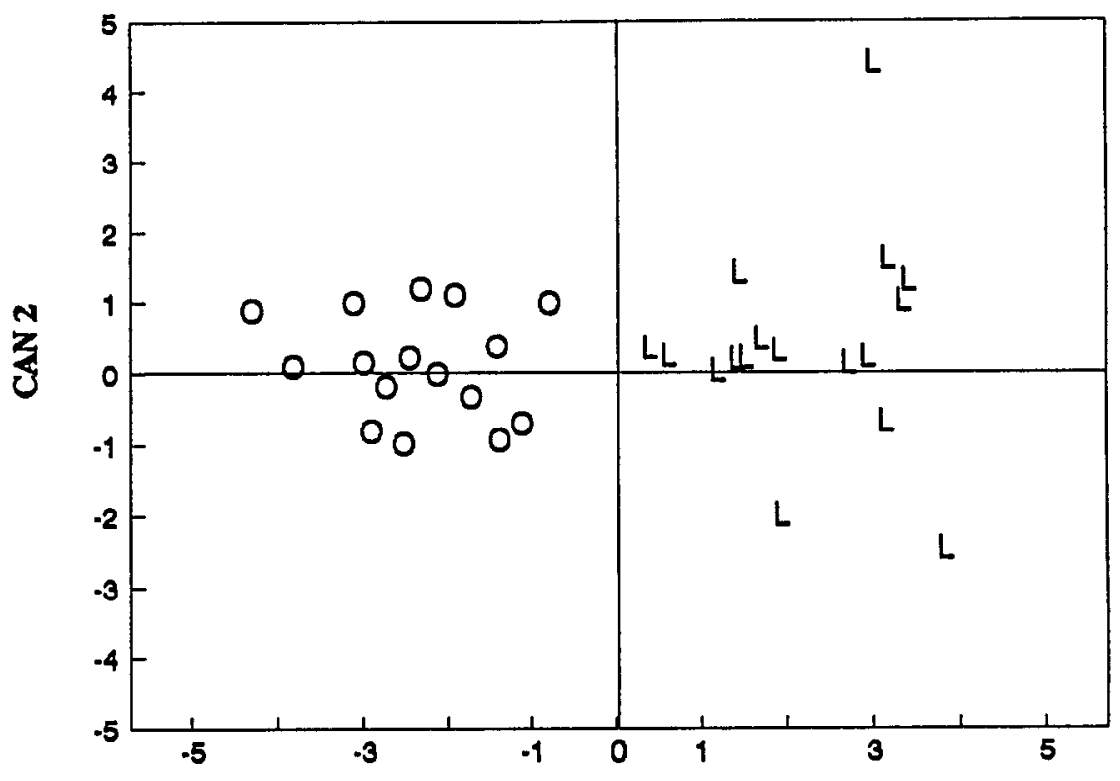

CAN 1

\section{O: Sheep L: Lama}

F. orthophylla, B. incarum, A. spinosisima, S. ichu

Gramadal annual grasses, P. candamoana, C. heteraphylla

Fig. 3. Canonic discrimination of selectivity of llamas and sheep for forages in the Bolivian arid highlands. 
Table 3. Digestion coefficients, intake, and performances of llamas and sheep consuming Festuca orthophylla.

\begin{tabular}{|c|c|c|c|c|}
\hline & \multicolumn{2}{|c|}{ Wet season } & \multicolumn{2}{|c|}{ Dry season } \\
\hline & Llama & Sheep & Llama & Sheep \\
\hline $\begin{array}{l}\text { D.M. } \\
\text { O.M. } \\
\text { C.P. } \\
\text { C.F. } \\
\text { E.E. } \\
\text { N.F.E. }\end{array}$ & $\begin{array}{l}\text { Digestio } \\
54.2^{\mathrm{a}} \\
56.9^{\mathrm{a}} \\
59.7^{\mathrm{a}} \\
64.2^{\mathrm{a}} \\
45.8^{\mathrm{a}} \\
48.5^{\mathrm{a}}\end{array}$ & $\begin{array}{l}\text { Coeffici } \\
41.4^{\mathrm{b}} \\
42.3^{\mathrm{b}} \\
52.0^{\mathrm{b}} \\
50.5^{\mathrm{b}} \\
17.9^{\mathrm{b}} \\
31.9^{\mathrm{b}}\end{array}$ & $\begin{array}{r}41.3^{\mathrm{a}} \\
47.7^{\mathrm{a}} \\
-60.5^{\mathrm{a}} \\
59.4^{\mathrm{a}} \\
-18.4^{\mathrm{a}} \\
40.7^{\mathrm{a}}\end{array}$ & $\begin{array}{r}39.4^{\mathrm{a}} \\
42.4^{\mathrm{b}} \\
-57.2^{\mathrm{a}} \\
52.6^{\mathrm{b}} \\
26.5^{\mathrm{b}} \\
35.9^{\mathrm{a}}\end{array}$ \\
\hline $\begin{array}{l}\text { intake } \\
\text { (g/head/day) }\end{array}$ & $\begin{array}{c}\text { Intake an } \\
1000.1\end{array}$ & $\begin{array}{l}\text { Perform } \\
377.5\end{array}$ & 695.3 & 300.6 \\
\hline $\begin{array}{l}\text { Intake } \\
\left(\mathrm{g} / \mathrm{Kg}^{0.75} / \text { day }\right)\end{array}$ & $34.2^{\mathrm{a}}$ & $40.2^{b}$ & $24.4^{\mathrm{a}}$ & $30.8^{b}$ \\
\hline $\begin{array}{l}\text { Intake } \\
\text { (\% live weight) }\end{array}$ & 1.1 & 1.9 & 0.8 & 1.4 \\
\hline $\begin{array}{l}\text { Metabolizable } \\
\text { energy } \\
\quad\left(\mathrm{kcal} / \mathrm{KgW}_{\mathbf{g}} \mathbf{0}^{0.75}\right)\end{array}$ & 68.7 & 60.1 & 40.4 & 47.9 \\
\hline $\begin{array}{l}\text { liveweight } \\
\text { (g/head/day) }\end{array}$ & +140 & -61 & -618 & -282 \\
\hline
\end{tabular}

Means in row with different superscripts, by season, differ $(p<0.05)$.

Schneider 1977), which could greatly improve microbial fermentation with low quality diets.

Intake of paja brava was low in relation to the levels of intake previously reported (San Martin and Bryant 1989). This lower intake has to be related to the very low quality of the forage used (Table 2). For the 2 experimental trials, intake (in $\mathrm{g} / \mathrm{KgMBW} / \mathrm{d}$ ) was always lower in llama than in sheep, with a difference of 15 and $21 \%$ in wet and dry periods, respectively.

Llama gained $140 \mathrm{~g}$ during the wet period, while sheep lost $61 \mathrm{~g}$ daily. Estimates of dietary metabolizable energy indicated that llamas could meet maintenance requirements $(61.2 \mathrm{Kcal} / \mathrm{kg}$ $\mathrm{MBW} / \mathrm{d}$; Engelhardt and Schneider 1977) during the wet period. However, sheep maintenance requirements are $60 \%$ higher $(98$ $\mathrm{Kcal} / \mathrm{kg} \mathrm{MBW} / \mathrm{d} ; \mathrm{NRC} 1975$ ) and exceed the energy content of paja brava (Table 3). During the dry season trial, energetic supplies were not sufficient to meet requirements in both llamas and sheep.

\section{Conclusion}

Dominant rangelands of the arid bolivian highlands support poor quality forages. Nevertheless, livestock production is an important activity of this zone. Mixed herds of llamas and sheep allow a better utilization of the overall available forage. Llamas, due to their forage preferences and digestive physiology, are able to use the dominant bunchgrasses of the area better than sheep. These plant species are well adapted to the environment and can support camelid production during the wet season. Sheep are more dependent upon the presence of short grasses and forbs communities (bofedal and gramadal). During the dry season, however, forage is scarce and rough. Mortality is high, especially in young animals. Management should emphasize eventual feed alternatives to meet nutritional requirements of the animals during this season, such as chemical treatment of coarse bunchgrasses or adapted cultivated forages supplementation.

\section{Literature Cited}

Alvarez, J.B. 1993. Diponibilidad, selectividad y valor nutricional de las dietas de alpaca, llama y ovinos al pastoreo libre, durante el periodo secano en la puna seca. M.S. Thesis, Univ. Nacional Agraria, La Molina, Peru. 144 p.

Alzerreca, H. and A. Cardozo. 1991. Valor de los alimentos para la ganaderia andina. Serie tecnica IBTA/SR-CRSP/001, La Paz, Bolivia.

Alzerreca, H. and R. Lara. 1988. Evalucion de praderas nativas en el altiplano central y oeste del Departamento de Oruro. In: Mem. I ra Reunion Nacional en Praderas Nativas de Bolivia. CORDEOR-PAC, Oruro, Bolivia. 3-11.

Engelhardt, W. and W. Schneider. 1977. Energy and nitrogen metabolism in the llama. Anim. Res. and Develop. 5:68-72.

Genin, D. and A. Badan. 1991. Goat herbivory and plant phenology in a mediterranean shrubland of northern Baja California. J. Arid Environ. 21:113-121.

Genin, D. and P. Pijoan. 1993. Seasonality of the goat's diet in the coastal scrub of Baja California. Small Ruminant Res. 10:1-11.

Hanley, T.A. and K.A. Hanley. 1982. Food resource partitioning by sympatric ungulates on Great Basin rangeland. J. Range Manage. 35:152 - 158.

Lailhacar, S. 1990. Evaluacion nutritiva de los recursos forrajeros nativos y naturalizados de la Ira Region de Chile. Avances en Produccion animal. 15:61-80.

Maiza, R. and A. Cardozo. 1992. Digestibilidad del ichu (Stipa ichu) en ovinos, llamas y vicunas. In: Mem. X Reunion de Asociacion Boliviana de Produccion Animal. La Paz, Bolivia, 18-20/10/1990. DANCHURCHAID-IBTA. 53-54.

Meuret, M., N. Barthiaux-Thill, and A. Bourbouze. 1985. Evaluation de la consommation d'un troupeau de chevres laitieres sur parcours forestier. Ann. Zootech. 34:159-180.

Morgan, D.E. 1974. Development of laboratory methods of estimating the digestibility and energy value of forages. London, Her Majesty's Stationery Office. Agr. Dev. and Advisory Serv. Annual Rep. 94-103.

Moron, E., H. Alzerreca and D. Genin. 1992. Caracterizacion de un campo nativo de pastoreo en el altiplano arido de Oruro. In: Mem. XI Reunion Asociocion Boliviana de Produccion animal. Oruro, Bolivia, 21$-23 / 10 / 1992$. In press.

NRC. 1975. Nutrient requirements for sheep. National Academy of Sciences, Washington, D.C.

Nolan, T. and J. Connolly. 1977. Mixed stocking of sheep and steers-A review. Herb. Abstr. 47:367-374.

Ortega, I.M. 1991. Deer and cattle foraging strategies under different grazing systems and stocking rates. PhD Thesis, Texas Tech Univ., Lubbock, Tex. 152 p.

Pfister, J., F. San Martin, L. Rosales, D.V. Sisson, E. Flores, and F.C. Bryant. 1989. Grazing behavior of llamas, alpacas and sheep in the Andes of Peru. Appl. Anim. Behav. Sci. 23:237-246.

Reppert, J.N. 1960. Forage preferences and grazing habits of cattle at the Eastern Colorado Range Station J. Range Manage. 13:58-62.

San Martin, F. 1987. Comparative forage selectivity and nutrition of south american camelids and sheep. PhD Thesis, Texas Tech Univ., Lubbock, Tex. $146 \mathrm{p}$.

San Martin, F. and F.C. Bryant. 1989. Nutrition of domesticated south american llamas and sheep. Small Ruminant Res. 2:191-216.

Steel, R.G.D. and J.H. Torrie. 1980. Principles and procedures of statistics. 2nd ed. McGraw-Hill, N.Y. 633 p.

Stobbs, T.H. 1973. The effect of plant structure on the intake of tropical pasture. I-Variations in the bite size of grazing cattle. Australian. J. Agric. Res. 24:809-819.

Villca, Z. 1993. Comportamiento alimenticio de llamas y ovinos en un sistema de pastoreo tradicional de altiplano central de Bolivia. Tesis Ing. Agronomo. UTO, Oruro, Bolivia. $110 \mathrm{p}$.

Wheeler, J.C. 1991. Origen, evolucion y status actual. In: S. FernandezBaca. Avances y perspectivas del conocimiento de los camelidos sudamericanos. FAO. Santiago. Chile. 11-48. 